\title{
The Right of the Governed: Foucault's Theoretical Political Turn
}

\author{
João Leite Ferreira-Neto ${ }^{1}$ *
}

${ }^{1}$ Pontifical Catholic University of Minas, Departament of Psychology, Av: Dom José Gaspar, 500. Coração Eucarístico - Belo Horizonte - MG. 30535-901, Brazil.

\section{KEYWORDS}

Michel Foucault

Governmentality

Subjectivity

Neoliberalism

Welfare State

\section{ABSTRACT}

This paper aims to understand the theoretical-political turn of Foucault constructed from 1978, which led him to a distancing from the Maoist left and to a return to the notion of subjectivity within a perspective of liberty, in the context of his governmentality studies. The historicalinstitutional aspects relating to his theoretical and political shift will be discussed, with basis on biographical sources and texts by the author published at that time. The conclusion is that Foucault used both Marxist and neoliberal contributions, avoiding reducing the politics to a confrontation between two projects, but considering it a complex field of plural strategies. He also began to theorize about the rights historically known as the 'right of the governed,' led by the question: 'how to become subject without being subjected?'.

\section{Introduction}

Michel Foucault has become a reference for research in the human and social sciences all over the world, notably in English-speaking countries. The publication of the book 'The Foucault Effect' (Burchell, Gordon, and Miller 1991) marked the beginning of a growing interest in the philosopher's work, particularly in Britain, Australia, and Canada, which has since gradually

*Contact address: jleite.bhe@terra.com.br (J. L. Ferreira-Neto). 
increased. This expansion of Foucault's influence began in the 1970s with his visits to the United States and Canada and with the translation of Discipline and Punish (Foucault, 1977a). In a survey carried out in 2007 by Times Higher Education, Foucault was considered the most cited name in the human and social sciences in the last few decades (Kelly 2014). In the social sciences field, his focus was on 'Governmentality Studies', investigating the conduct mechanisms of people, individuals, or groups.

Since 1997, the publication of Michel Foucault's courses at Collège de France, has shed new light for the study of his previously published work. One of the themes that emerged most strongly was governmentality. The theme was developed in the lectures Security, Territory, Population from 1978 and The Birth of Biopolitics from 1979, gaining strength in the following years, and demonstrating itself to be a crucial concept in the architecture of his work. Both lectures focus on the study of the reason of State from the 17th century to the $20^{\text {th }}$ century, with the second course giving special attention to neoliberal governmentality.

Besides a new theoretical inflection, texts from this period also indicate a change in his political position, which still provokes several debates. The fact that Foucault showed an interest in the neoliberal project, without criticizing it, produced some interpretations, among which, that he may have adhered to neoliberalism. Recent publications have raised this debate, (Zamora 2014), leading to a variety of reactions (Audier 2015; Dean 2015).

His 1979 lectures on neoliberalism were revealed to be premonitory. A month after it finished, Margaret Thatcher was elected prime minister of the United Kingdom and, at the end of the year, Ronald Reagan was elected president of the United States. Both are considered heralds for the implementation of neoliberal policies, which up to that point had merely appeared in a few isolated initiatives in Helmut Schmidt's Germany and Giscard d'Estaing's France, both discussed by Foucault, but without reaching the hegemony in the political-economical debate that it would conquer in the 1980s and 1990s. 
As from 1978, the notion of governmentality, or of government, began to occupy a central place in Foucault's research, acting as a conductor for a certain turning point in his theoretical and political positioning (Gamez 2018). He began to consider power, less as a matter of 'a confrontation between two adversaries,' as he asserted in the first half of the 1970s, but as a matter of government. This must be understood within a broader meaning, regarding both the political structures and management of the State and 'the way in which the conduct of individuals or groups might be directed' (Foucault 2000a, 341). Besides this, it involves what he begins after 1980 to call 'government of self.' This is, therefore, a concept that embraces both the individual and the collective and includes the institutional macrostructures. It is a transversal concept, which permeates a variety of dimensions of institutional life, collective and individual. When elaborating this notion in 1978, Foucault affirmed that while pastoral power - the seed of modern governmentality - created the first draft of man's government, at the same time it also whetted another appetite: 'how to become subject without being subjected?' (Foucault 2007, 308).

Government was revealed to be an operational concept, allowing both a study of the governmentality of the State and the ethics of subjectivation, as indissociable processes. For the first time, subjectivity began to be thought of as a distinct facet of the tamed soul of power, of coercive practices, which were until then the focus of his research. From that point on, Foucault was able to explore the practice of self as a practice of freedom, the last theme he would study.

Fraser (2003) suggests that Foucault anticipated the contemporary times of scattered and destatized governance. Since the 1980s, the concept of governance has emerged in the social sciences to deal with two problems. On the one hand, the growing dependence of the state on civil society organizations; on the other, states that were increasingly tangled up in international settings (Bevir 2012). He proposes that, although the concept of governmentality has some themes in common with the concept of governance, the first one pays 'particular attention to the diverse meanings 
within it and the contingent historical roots of these meanings' (Bevir 2010, 436). Our aim here is not to explore the approximations and differences between concepts, a discussion present in the literature (Dean 2007; Jessop 2016). But to try to understand how the concept of governmentality led Foucault to review certain political positions.

This article aims to understand the theoretical-political positions that Foucault constructed after 1978, establishing the notion of governmentality as a central axis for his research, and of subjectivity as a political and ethical dimension. Initially, historical aspects will be discussed, based on the 'Course Context' written by Senellart (2004), biographical data, in dialogue with texts written by Foucault between 1977 and 1980. In the second place, the article will analyse a 1983 interview on the French welfare system crisis, seeking to understand his positioning regarding the theme (Foucault 2000). The choice of this interview over his lectures on neoliberalism took place for two reasons. The first is prevalence in literature. While The Birth of Biopolitics is Foucault's most commented work, this interview has been 'almost completely ignored by the governmentality literature, and rarely cited by Foucauldians' (Dean 2016, 102). The second is the way it approaches practical aspects of a central theme in the debate between Keynesians and neoliberals: the welfare system crisis.

My central argument follows the interpretation by Flew $(2012,49)$, among others, that Foucault's political position occupies 'a more ambiguous political space' than frequent interpretations suggest, in which he is still situated as a left-wing thinker. As we shall see, if on the one hand, Foucault did not become a neoliberal, on the other hand, his political position should no longer be considered within left-right binary conventions. He is better understood as having developed a critical ethos that led him to an incessant intellectual movement characterized as a 'non-normative form of critique' (Trianfillou 2012; Hansen, 2014). Along with this path, Foucault constructed a political perspective that favours, within the sphere of government relations, the point of view of those who are governed - what he calls the right of the governed (Foucault 1994c). 


\section{From war to government: historical aspects}

The initial hypothesis is that in 1977, his sabbatical year from the Collège de France, a turn occurred in Foucault's political and research trajectory. Senellart (2007) asserts that the philosopher moved the centre of gravity of his lectures from the matter of biopower, to that of government. The prevalent interpretation in literature, although not exclusive, is that Foucault abandoned the notion of biopolitics in favour of the notion of governmentality. Castro-Gómez $(2011,63)$ considers biopolitics a provisional concept that 'fulfils the role of a bridge between the military model and the governmental model.' Even though it was announced in his 1979 title, The Birth of Biopolitics, the concept is not explored in the lecture nor is it pursued by the philosopher in later texts, except an answer given in an interview.

Senellart (2008) highlights three episodes that contain enlightening elements of the historical conditions that led to Foucault's construction of the theme of governmentality and the changes in his political positioning: his growing proximity to the so-called French 'Second Left'; his involvement with the Klaus Croissant case; and his work on 'reporting ideas', carried out during the Iranian revolution.

Regarding the first episode, in June 1977, during the Socialist Party convention, Michel Rocard distinguished two left-wing political cultures. The first, Jacobin and focussed on State, and the second anti-statist and decentralizing, which became known as the Second Left (Defert 2013). The latter distanced itself from classic Marxism, incorporating themes such as daily life, the situation of women, and self-management, among others, elaborating an agenda close to that of May '68 and Foucault himself. Months later, in September, Foucault was an active participant in a forum on the left and social experimentation, defending that innovation no longer passed through political parties, but through the individual ethical restlessness (Foucault, 1994b). Behrent $(2016,38)$ understands that Foucault's interest in neoliberalism was a result of his proximity to the Second Left.

It is worth pointing out the reason we can talk about a political turn for Foucault during this period. In his youth, Foucault was a member of the 
Communist Party but left in 1953. For many years he used Marxists concepts in some of his texts and interviews but abandoned them progressively. When Foucault returned to France After May '68, he found part of the left moving away from the Soviet experience in favour of Chinese Maoism. When he took on a management role in the recently-created Centre Universitaire Expérimental de Vincennes, he nominated several militant Maoists such as Alain Badiou, Jacques Rancièrre, André Glucksman, and Jacques-Alain Miller, attuned to the institution's political spirit: to lecture Philosophy it was necessary to have taken part in May '68 and to belong to one or another political group (Eribon 1990). Foucault was very close to one of these groups, the Gauche Prolétarienne.

The Gauche Prolétarienne sought to involve popular participation from the textile sector, to carry out research on the daily life of people, and to establish a form of popular justice. According to Karlsen and Villadsen (2014), Foucault's genealogical work for the Information Group (GIP) on prisons was clearly inspired by Maoist investigation techniques, as well as their military power model. The GIP shared the idea of the French left which conventional politics were an epiphenomenon that hid 'the real mechanisms of oppression' $(2014,104)$.

Foucault's proximity to the Maoist left did not imply an integral adhesion to their theses and methods, as can be seen in his debate on Popular Justice with Maoist militants (Foucault 1994a). His connection with Nietzschean genealogy allowed him to maintain an important critical distancing from Maoism, while at the same time drinking from that source. Even so, he ended up disengaging himself from that influence, losing his belief in the idea of revolution and mainly in violent strategies of the political fight, as the following episode demonstrates.

The second element that involves Foucault's political turn was his decisive support for the non-extradition of Klaus Croissant, a lawyer defending the Baader group ${ }^{1}$. Foucault did not measure his efforts in this

\footnotetext{
1 The Baader group were connected to the West German far-left Red Army Faction (RAF), which committed a series of bombings and other terrorist attacks during the 1970s. Croissant asked for the right to asylum in France, where he had found refuge in July 1977 (Senellart 2007).
} 
endeavour, writing several texts and manifestos, which we shall examine next, and participate in public demonstrations. Even so, Croissant was extradited at the end of 1977.

As Eribon (1990) reminds us, Foucault's position was no longer left wing. This led him to break away from one of his dearest friends, Gilles Deleuze. During this case, Foucault wanted to defend the lawyer, but not his clients, who he considered terrorists, refusing for this reason to sign a second broader manifest, signed by Guattari and Deleuze, which among other things accused Germany of having become a police state. After that, he distanced himself from his friend. Years later, he would confide to Mauriac his reason for withdrawing from Deleuze, ever since Klaus Croissant: 'I couldn't accept terrorism and blood, I did not approve of Baader and his gang' (Eribon 1990, 242). Later, in his final years, Foucault revealed a desire to meet with Deleuze. This didn't take place, but it was Deleuze who, invited by Defert, conducted Foucault's burial ceremony, with an emotional reading of part of his work.

But what was the theoretical debate constructed during the battle against Croissant's extradition? We can summarize his ideas from two texts from that period, in which Foucault touches upon the case. In the first text, he defends Croissant, in the name of the rights of the governed, considered 'more historically determined than the rights of men,' but which as a theory still lacked elaboration (Foucault 1994c, 362). After 1978, his lectures draft the format of this theorization, going from the concept of governmentality and counter-conducts to that of parrhesia. That same year he describes as a form of critique that which in his 1979 lecture he would associate to the emergence of liberal democracies: 'how not be governed like that' (Foucault 1997b: 44). This point of view, wary of government and supportive of a revolt of the governed, would become central to his new political positioning. Some years later he would affirm that no form of government has the vocation to respect human rights, adding: 'human rights are the rights of the governed' (Foucault 2014, 266). 
In November 1977, after Croissant's extradition, Foucault gave an interview where he recognizes the left's omission in the affair, pointing out how it is hard to do the 'criticise or self-criticise the left' (1994d, 383). He announces the emergence of societies of security, in which the State enters a pact of security with the population, offering a guarantee against all doubt using a welfare system. This leads to a tendency towards State totalitarianism, with the need to carry out precise control over everything, a theme he will return to in the 1983 interview. However, Foucault separates this on-going Western experience from totalitarianism in a strict sense, where the political parties, the State apparatus, the institutional systems, the ideology, adhere to a sort of unit which is controlled from top to bottom, without fissures. According to him, we cannot label the liberal democracies as fascist States, despite their tendency towards an extreme control over their populations, in the name of security. Foucault wagers on the political consciousness of the people who don't buy the idea that they live in a fascist State, a strong element in left-wing rhetoric. In truth, people know that the constant vigilance of the mechanisms of social security 'is not a matter of fascism, but of something new' (Foucault 1994d, 387). Foucault's interest is in the analysis of the emergence of security technologies. He does not condemn these a priori but makes a counterargument for the art of not being governed in a determined manner; the historic right of the governed.

The third episode mentioned by Senellart (2007) was Foucault's involvement in a 'reportage of ideas' on the Iranian revolution for an Italian periodical. It will not be possible in this space to analyse what would be one of the most polemical episodes in Foucault's biography. Senellart (2007) has carried out a good summary of this debate. I will simply point out that Foucault visited the country twice at the start of the protests, the second visit occurring in November 1978 during the biggest demonstrations against the Shah, but before his fall and the instalment of 'the bloody government of an integrist clergy' in February 1979 (Foucault 2000c, 451).

The fact is that Foucault was enamoured by what he witnessed and, while following the Iranians, he does not call this a revolution, but a 
demonstration, an insurrection, giving it a similar status to that which he called counter-conduct (Foucault 2007). With Ayatollah Khomeini's rise to power, marked by extreme violence against the regime's opposition, Foucault was harshly criticised both by the left and the right. He didn't engage in controversy, but wrote an article for Le Monde in May 1979 entitled 'Useless to revolt?' (Foucault 2000c).

In this article, Foucault affirms the importance of insurrections, individual and collective, which demand a non-obedience to power. He carefully makes a distinction between insurrection and revolution, at the time a parameter for left-wing thinking. According to him, what happened in Iran is something new about Western standards. He noted a spirituality in the men and women who risked their lives revolting against the Shah, different from the bloody violence of the fundamentalist clergy that would follow. The moment he values is when 'a singularity arises.' Therefore he does not agree with the argument that: 'It is useless for you to revolt; it is always the same thing' (Foucault 2000c, 452). An insurrection defines the moment in which a commonplace subjectivity introduces itself into the story, breathing life into it, a subjectivity that is not exclusively psychological, but has a political and ethical bias. In the end, Foucault insists that power is not necessarily evil; however, it is interminable. For this reason, it is necessary to impose rules, limits, and restrictions, always.

Besides the episodes listed by Senellart, we can add a practice, distinct from those that came before. Foucault held a private seminary alongside his lectures for the Collège de France. Between 1976 and 1980, this is where he would broaden his political discussion (Behrent 2010), and it would become a laboratory to produce a new political philosophy that would offer an alternative to Marxism. Activists from the 1968 generation were a part of this venture, among them François Ewald, Alessandro Fontana, Giovanna Procracci, and Pierre Rosavalon, an economist linked to the Second Left. Part of these studies was explored during his official lectures of 1978 and 1979. Later, several of these students produced work on public policies and the Welfare State, and some acted as consultants for the French government. 
Based on testimony from some of the participants, Behrent's study (2010) describes the seminars from this period as fulfilling a role of a sort of political group therapy for their previous Maoist involvement, based not on psychoanalysis but historical studies. The concept of governmentality helped Foucault and the members of his seminary to understand the centrality of the Welfare State in the power arrangements of the modern State - a discovery that demanded, according to Ewald, nothing less than a 'spiritual conversion'. The research group generated a new appreciation for the complexity of modern governmental techniques as not merely repressive and disciplinary, but also as 'open and playable' (Behrent 2010, 587), breaking with the moralist Manichaeism that denounces power as necessarily oppressive. They realized that these 'new philosophical politics' of Foucault offered not only a path to abandon Marxism, but also an alternative to the left-wing politics of moral denunciation. Eribon highlights the importance given by Foucault to these private lectures, which linked his work to that of his students, as a highly valued space for intellectual work (1990).

In 1978, while talking with a Japanese interlocutor, Foucault stated that Marxism is an 'object from which one needs to disengage' (Foucault 1994e, 599). And to outgrow Marxism, it is necessary to 'not fall into a trap of traditional solutions' (p. 601). It is important to create new political imaginary, and not simply take over already existing notions. The construction of these political imaginary involves working with the self - a process of subjectivation. This is one of the dimensions of the intellectual work emphasized by Foucault. In an interview given to Ewald, he affirms: 'A work, when it's not at the same time an attempt to modify what one thinks and even what one is, is not much fun' (Foucault 1889, 293). In this manner, the subjectivation is established both in the political insurrection in the face of a specific situation and in intellectual insurrection relating to theoretical traditions and to what was thought previously.

In sum, Foucault, from 1977 onwards, developed a political reflexion on 'the art of not being governed in such a manner,' about the rights of the 
governed, and about insurrection. This demanded that he return to the notion of subjectivity, no longer understood as docility, submission, but as a practice of freedom. The critique from that point on will be 'the art of voluntary insubordination, that of reflected intractability' (Foucault 1997b, 47). This critical process involving the task of thinking differently, of letting go of former beliefs and the self, permeated the atmosphere of his private lectures in the discussions about governmentality and the Welfare State.

\section{Neoliberalism and welfare state crisis}

Foucault always refused to be classified by some political position of principles, being capable of listing several to which his identity had been linked, whether anarchist, Marxist, anti-Marxist, nihilist, or even neoliberal (Foucault 1997a). However, in the summary for his 1979 lecture, he based himself on an evaluation by Paul Veyne, defining his work identity as 'a nominalist method in history' (Foucault 2008, 318). During the same lecture, he directed his work proposing: 'Let's suppose that universals do not exist' (Foucault 2008, 3). He had taken this path in his previous work on madness and in his discussion on the State. Foucault does not take these as universals but scrutinizes the set of practices that make them emerge. We should understand his analysis of neoliberalism from this perspective.

This methodological nominalism led Foucault to a type of political critique that can be classified as predominantly non-normative, or descriptive. I highlight the 'predominantly,' understanding that, even parsimoniously, Foucault defends certain values, upon which he anchors his critique, as we will see in the interview to be analysed further along.

About neoliberalism, part of Foucauldian literature is careful to denounce the abusive use of this concept. Cotoi (2011) suggests that neoliberalism became a generalizing fad (one of the buzzwords), by designating both in academia and in the press the political practices one wishes to criticise. This is particularly strong in Marxist literature, such as in 
the work of Dardot and Laval (2016), which despite being partially inspired by Foucault, presents neoliberalism as the 'new reason for the world.'

Flew $(2012,45)$ analyses the proliferation of the use of the term as having a content of moral denouncement, or a way to refer 'to the bad ideas held by others.' Indeed, it isn't rare that someone will argue in a debate: 'this is neoliberal,' as a disqualifying strategy, instead of taking time to deepen specific arguments of discord. I agree with Kipnis (2008), in his anthropological studies on the evaluation culture in China, when he considers that the classification of a neoliberal governmentality 'masks more then they illuminate' the analysis (p. 280). He also states that the detailed examination of the implementation of evaluation technologies in different contexts is more important than an 'ideological critique of neoliberalism per $\operatorname{se}^{\prime}$ (p. 285).

This generalizing use of the notion of neoliberalism is distant from the discussion carried out by Foucault, who didn't take it as a universal abstract, instead of analysing it in its local dimensions: German and American neoliberalism, with the last being the Chicago School. Both possess historical-institutional differences as well as some common characteristics. The opposition to Keynes' proposals, which subsidized the construction of the welfare states; the critique of state interventionism; and the inspiration from the Austrian economic school of Von Mises and Hayek (Foucault 2008). These neoliberalisms sought to generalize the 'enterprise' format for society, using the state apparatus to guarantee competition, while at the same time restricting state discretion.

Two elements led some authors to suppose a certain alignment of Foucault with neoliberalism. One was the description made by Foucault regarding the emergence of a new art of government in the $18^{\text {th }}$ century, liberalism, as a critique of the excess of government (this is not yet neoliberalism). This is, therefore, 'the art of the least possible government' (Foucault 2008, 28). This new government rationality seeks to self-limit the government, no longer based on rights, but based on the political economy, understood in a broad sense as a method of government that aims to assure 
the prosperity of a nation. Among other facets, it interrogates government practices not 'to determine whether or not they are legitimate regarding right,' but for their effects (p. 15). It substitutes, in this manner, legitimacy through success, or, in contemporary language, through results.

There is a striking similarity between liberal reason and what Foucault calls critique, as well as his care in establishing restrictions to power, in the name of the right of the governed. Based on the previous argument that Foucault aimed to build a 'new political imaginary,' this apparent proximity between genealogical critique and the liberal art of government should not be taken as a mark of identity. If Foucault returns to liberalism and explores neoliberalism, it is as part of his trajectory in building a new political philosophy, not Marxist, but also not a transferral of liberalism, even if inherent to the liberal democracies he lived in.

The second factor stems from the fact that, when describing American neoliberalism, Foucault makes it clear that he renounces forging an exclusively disciplinary society, instead looking at a society 'in which there is an optimization of systems of difference, [...] in which minority individuals and practices are tolerated' (Foucault 2008, 259-260). Behrent (2016) reminds us that 'difference,' 'tolerance,' and 'minority practices,' are expressions commonly associated with the Foucauldian political ideology. Audier (2015) reports that, before giving his lectures on governmentality, Foucault was impacted during his trips to California with the freedom of sexual practices and drug use, besides the vigour of the homosexual community in San Francisco. Indeed, the American (neo)liberal society was the protagonist for the construction of minority policies, while the liberal government of Giscard d'Estaing was also advancing in the same direction with changes of legislation. Foucault observed in these practices of (neo)liberal tolerance a harbinger of the disciplinary order crisis and the emergence of other forms of less disciplinary government, operating using security technologies, a central theme in his lectures from 1978 and 1979.

The interview ceded to Robert Bono in 1983 was published in a book with works on welfare state, written by intellectuals linked to the French 
Second Left. With the title 'The risks of security'2 (Foucault 2000b), it discusses how to deal with the crisis that began ten years previously, linked to the odds between the growing demand for welfare and the limits of this system.

In his first intervention, Foucault points out the three elements that restrict his analysis: the welfare system created in 1946, which now clashes with known economic obstacles; his conceptual model, now depleted; and that the system has perverse effects, due to the rigidity of certain elements and the production of dependencies. In the interview, the three points do not have the same importance. In truth, the first two form a certain framework for the debate. But the third is the central axis of Foucauldian problematization. It is the most explored in the interview and sketches out what would be a desirable path for welfare, with the notion of autonomy as a backdrop. This alternative will be presented, in an exploratory manner, during the interview. An analysis of this interview will be made using this framework, the three problematic points of welfare, and an experimental alternative to be implemented.

The first point, the economic limits placed upon the welfare system, is an argument with neoliberal origins. Foucault does not problematize the economic limit placed on the system but explains how, in the field of health, this limit manifests itself. According to him, among the technical capacities of medicine and the economic capacities of a collectively, there is a mobile line that tends to an imbalance due to the permanent rise in demand. He emphatically affirms, 'I do not see, and nobody can explain to me, how technically it would be possible to satisfy all the needs of health along the infinite line on which they develop' (Foucault 2000b, 375). The title of the conversation came from this condition, and other aspects of this matter are explored within the other points.

With the second point, Foucault explores the antiquity of the social model upon which the State-Provider is based. He points out it was

\footnotetext{
2 The English translation differs from the original French: 'Une système fini face à une demande infinie' (Foucault 1994f, 367).
} 
conceived in the first half of the 20 th century, attributing its ideology to Beveridge and Keynes from England. He considers this to have been a work of great importance, but which has not kept current with the changing times, with nothing new emerging, something that became clear in the crisis that had already lasted ten years. Remembering that when it emerged, welfare sought to face what we can call 'the needs of health.' In other words, 'with invalidating deviations linked to sickness and congenital or acquired handicaps' (p. 373). Currently, with the evolution of medical technologies and the rise in the demand for health, there has been an unlimited growth in what can be considered health accidents or shortcomings.

His diagnosis is that 'we lack completely the intellectual instruments to envisage in new terms the framework within which we could achieve our goals' (Foucault 2000b, 370). Foucault's understanding is that this crisis cannot be equated simply by managing economic limits, as seen in the previous item. It will be necessary to construct new intellectual instruments, or, to use contemporary language, new social technologies.

The third point analyses the perverse effects of the system. The most explored aspect is the effect of the dependency that stems from an offer of security by the State. Foucault states that after the war the matter of security was, in fact, vital. Later, after the 1960s, the theme of independence emerged in the social arena. Dean (2016) suggests that this is the neoliberal diagnosis, that the Welfare State generates a dependency, irresponsible and costly. However, Foucault's evaluation moves beyond this neoliberal simplification. He distinguishes dependency by integration, which makes up the neoliberal diagnosis, from dependency by exclusion, pointing out the failure of universalization policies and emphasizing: 'We need to respond to both threats' (Foucault 2000b, 367). Foucault also points out that welfare submits to individuals and groups to a determined 'way of life,' and when this is not reached, it produces marginalization (p. 369). Thus, if on the one hand, it is undeniable that Foucault takes on aspects of neoliberal perspective, on the other, he doesn't restrict himself to them but brings other elements to the debate that are foreign to neoliberal logic, such as the principle of 
universalization. This use of elements of neoliberalism may explain the reason he was labelled neoliberal; however, it doesn't justify it. It just reveals how Foucault did not blindly follow one political party line, or left-wing line, but sought to find tools in his studies that allowed him to think differently from the various political traditions. What we find, in this text and others, is a firm defence of the right of the governed, of a subjectification that produces normativity. Indeed, the etymologic sense of autonomy is exactly the capacity for self-government, for establishing one's own rules, which is a central axis of Foucauldian critique, possessing ineluctably a political-normative dimension.

By recognizing the impossible nature of the growth in expenditure at the rhythm it has tended to maintain, Foucault asks, who will decide that: state authority or the users? He then proposes a decentralization, 'in order to bring the users closer to the decision-making centres on which they depend and to tie them into the decision-making process' (p. 370). Foucault emphasizes the importance of what he calls decision distance, 'an optimal distance between a decision taken and the individual concerned' (p. 373). He understands one must know 'by what arbitration, always flexible, always provisional, the limits of access will be defined' (p. 375). His proposal is that these complex problems should not be faced by means of a single regulation, but through a 'decisional cloud', which allows variations, sustained by an 'ethical consensus, so that the individual can recognize himself in the decisions made and in the values behind the decisions' (p. 378). In this manner, the subject in the language of welfare is subjected to rules of bureaucracy and would become the subject that produces normativity, as well as that which questions its relation to the State. Unfortunately, according to the philosopher, we only question the nature of our relationship with the State once we face a loss or restriction of benefits, a decision taken by few.

In this wish to bring system users closer to measuring their choices, Foucault understands we would need to re-examine the presiding rationalities, since 'such choices are being made at every instant, even if left unsaid' (p. 367). In other words, governments constantly make choices in the 
field of public health, but system users are not always clear about the direction being taken. Thus, Foucault insists on the right of the governed to participate in decision-making, even if the structure of this process needs to be invented.

Foucault studies the past not to reproduce it, but to be able to think differently about our present. The solutions to current political issues are not in existing ideologies, Marxism or neoliberalism, although this did not stop him from seeking theoretical contributions from both, at the same time that he refused to take on either of these banners a priori. Dean $(2015,399)$ points out that Foucault demonstrated goodwill by adopting solutions borrowed from neoliberalism, on behalf of the French Second Left. Following the same line of thought, Colin Gordon suggests that Foucault could be read as challenging the socialists to observe the advances of social democracies, which carried out the selective incorporation of neoliberal strategies (Donzelot and Gordon 2008, 52).

This theoretical-political hybridism represented an effort made by the philosopher to escape the moralizing effects that binary classifications generate. He also sought to escape his theories of biopolitics, still centred in the notion of confrontation, and the 'power-resistance' pairing, which induced the idea that the political nobility belonged to the resistance and that the power is the evil. The notion of government allowed him to advance to more complex analyses, recognizing that the field of politics is a mixed and grey state, which cannot be captured by binary and moralizing classifications (Castro-Gómez 2011).

I tend to agree with the evaluation of his friend and collaborator Paul Veyne (2008), in his book on the thought and work of Foucault, who considers that, despite being deemed 'leftist', he was never a man of the left or the right, even if he strategically sought out leftists as partners in his occasional battles (p. 201). I have one consideration to make about Veyne's comment. In his relationship with Maoists and in his studies on neoliberalism, Foucault did not seem detached; on the contrary, he sought in 
them, without prejudice, references that would allow him to advance his analyses.

Another aspect worth highlighting regarding Foucault's position is his defence of 'the local character of the critique' (Foucault 2003, 6). The local is understood to be the analysis of an event through a precise historical and geographical extract, voiding generalizations. Therefore, the notion of counter-conduct, or of subjectivation, is not a political posture of principles, but a relational affirmation. Where 'transforming a specific situation' (Lorenzini 2016, 11) is sought at a localized level.

\section{Conclusion}

Foucault was not a Marxist or a neoliberal. Even so, he drank from both wells, mainly the first. Marx was an important intellectual influence for him. Between 1976 and 1980, he considered it necessary to 'disengage himself from Marxism,' however, he didn't consider it 'necessary to end Marx himself' (Foucault 1994e, 599). In his last years, he drew closer to the Second Left, on the one hand, while on the other hand, he was a combative critic of Mitterrand's socialist government, elected democratically in 1981. While analysing the French welfare crisis, he took in certain aspects of neoliberal critique but placed at the centre of his discussion the issue of autonomy and arbitration, which included user participation in defining possible limits to access. Foucault also understood that it was necessary to create a new political imaginary avoiding the trap of conventional solutions.

Foucault didn't declare his political identification with being a Marxist or a neoliberal. Instead of this Foucault $(2003,6)$ affirmed that there is a possible use of Marxism, on the condition that its 'theoretical unity of discourse is suspended, or at least, cut up, ripped up, torn to shreds.' We can understand that for Foucault, both Marxism and neoliberalism are not taken as a theoretical unity, but should be broken down into their constituent parts and exposed to their histories of the formation. 
I agree with the criticism made by some Foucauldians scholars about the generalizing use of the classification of neoliberalism, which ends up serving a function that is more rhetorical than analytical. The experience of many countries tends to operate with a mixture of tendencies in the field of public policy, combining recipes that are neoliberal and social-democratic in origin. Therefore, we have similar processes taking place in countries with different political traditions, as demonstrated by Trianfillou (2012) in his comparative study of Great Britain, Denmark, and France. Interpreting this as the global domination of neoliberalism sounds excessive and little descriptive. From a Foucauldian perspective, we would need to carry out a specific analysis of how these combinations take place, what strategic plays they favour or impair in local or national situations. In any case, Foucault did not reduce politics to the confrontation between two projects but considered it instead of a complex field with plural strategies of micropowers, which he began to explore within the perspective of governmentality.

Foucault's dive into classic political themes, such as State and political economy, through the micro-political lens of governmentality, led him to a complete shift towards subjectivation and ethics. This shift by Foucault had repercussions both in the theoretical plane and in the political plane. Extricating himself from Marxism was not simply an intellectual process, but a process of subjectivation, which brought costs and ruptures, both personal and institutional. Because of this, he began to theorize about the rights historically known as the 'right of the governed,' led by the question: 'how to become subject without being subjected?'. Thus, subjectivity for Foucault is placed in the interface between politics and ethics, also understood as care of self. The subject is an effect of practices of subjection and practices of freedom, produced in the cultural environment in which he lives.

Acknowledgement: The author received financial support for the research from National Council for Scientific and Technological Development, Brazil. (CNPq) Process: 310295/2015-7. 


\section{References}

Audier, Serge. 2015. "Neoliberalism through Foucault's eyes." History and Theory 54(3): 404-418. https:// doi.org/10.1111/hith.10768.

Behrent, Michael. 2010. "Accidents happen: François Ewald, the 'antirevolutionary' Foucault, and the intellectual politics of the French Welfare State." The Journal of Modern History 82(3): 85-624. https://doi.org/10.1086/653042.

Behrent, Michael. 2016. "Neoliberalism without humanism: Michel Foucault and the free-market creed, 1976-1979." In Foucault and Neoliberalism, edited by Daniel Zamora and Michael Behrent, 24-62. Cambridge: Polity Press.

Bevir, Mark. 2010. "Rethinking governmentality: towards genealogies of governance." European Journal of Social Theory. 13(4): 423-441. https://doi.org/10.1177/1368431010382758.

Bevir, Mark. 2012. Governance: A very short introduction. Oxford: Oxford University Press.

Burchell, Graham, Colin Gordon, and Peter Miller. 1991. The Foucault Effect: studies in governmentality. Chicago: The University of Chicago Press.

Castro-Gómez, Santiago. 2011. Historia de la Gubernamentalidad. Bogotá: Siglo del Hombre Editores.

Cotoi, Călin. (2011). "Neoliberalism: a Foucauldian Perspective." International Review of Social Research. 1(2): 109-124. https://doi.org/10.1515/irsr-2011-0014.

Dardot, Pierre and Christian Laval. 2016. A nova razão do mundo: ensaio sobre a sociedade neoliberal. São Paulo: Boitempo.

Dean, Mitchell. 2007. Governing societies. New York: Open University Press.

Dean, Mitchell. 2015. "Foucault must not be defended." History and Theory 54(3): 389-403. https:// doi.org/10.1111/hith.10767.

Dean, Mitchell. 2016. Foucault, Ewald, and Neoliberalism. In: Foucault and Neoliberalism, edited by Daniel Zamora and Michael Behrent, 85-113. Cambridge: Polity Press.

Defert, Daniel. 2013. Chronology. In: A Companion to Foucault, edited by Christopher Falzon, Timothy O'Leary, and Jana Sawicki, 11-83. Oxford: Blackwell.

Donzelot, Jacques, and Colin Gordon. 2008. "Governing liberal societies: the Foucault Effect in the English-speaking world." Foucault Studies 5: 4862.

Eribon, Didier. 1990. Michel Foucault, 1926-1984. São Paulo: Companhia das Letras. 
Flew, Terry. 2012. "Michel Foucault's The birth of biopolitics and contemporary neoliberalism debates." Thesis Eleven 108(1): 44-65. https://doi.org/10.1177/0725513611421481.

Foucault, Michel. 1989. The concern for truth. Foucault live. New York: Semiotext(e), pp. 293-308.

Foucault, Michel. 1994a. "Sur la justice populaire. Debat avec les maos." In Dits et Écrits II 1980-1988, 340-369. Paris: Gallimard.

Foucault, Michel. 1994b. "Une mobilisation culturelle." In Dits et Écrits III 1976-1979, 329-330. Paris: Gallimard.

Foucault, Michel. 1994c. “Va-t-on extrader Klaus Croissant?" In Dits et Écrits III 1976-1979, 361-365. Paris: Gallimard.

Foucault, Michel. 1994d. "Michel Foucault, la sécurité et l'Etat." In Dits et Écrits III 1976-1979, 383-387. Paris: Gallimard.

Foucault, Michel. 1994e. "Méthodologie pour la connaissance du monde: comment se débarrasser du marxisme." In Dits et Écrits III 1976-1979, 595-618. Paris: Gallimard.

Foucault, Michel. 1994f. "Un système fini face à une demande infinie." In Dits et Écrits IV 1980-1988, 367-382. Paris: Gallimard.

Foucault, Michel. 1997a. "Polemics, politics, problematizations." In Essential Works of Michel Foucault, vol. 1: Ethics, Subjectivity and Truth, edited by Paul Rabinow, 111-119. New York: The New Press.

Foucault, Michel. 1997b. "What is Critique." In The politics of truth, edited by Sylvère Lotringer, 41-81. Los Angeles: Semiotext(e).

Foucault, Michel. 1977c. Discipline and punish. Birth of the prisons. New York: Random House.

Foucault, Michel. 2000a. "The subject and power." In Essential Works of Michel Foucault, vol. 3: Power, edited by James D. Faubion, 326-348. New York: The New Press.

Foucault, Michel. 2000b. "The risks of security." In Essential Works of Michel Foucault, vol. 3: Power, edited by James D. Faubion, 365-381. New York: The New Press.

Foucault, Michel. 2000c. "Useless to revolt?" In Essential Works of Michel Foucault, vol. 3: Power, edited by James D. Faubion, 449-455. New York: The New Press.

Foucault, Michel. 2003. Society must be defended. Lectures on Collège de France 1975-1976. London: Alen Lane.

Foucault, Michel. 2007. Security, Territory, Population. Lectures on Collège de France New York: Palgrave Macmillan.

Foucault, Michel. 2008. The Birth of Biopolitics. Lectures on Collège de France. New York: Palgrave Macmillan. 
Foucault, Michel. 2014. Wrong-Doing, Truth-Telling: the function of avowal in justice. Chicago: University Chicago Press.

Frazer, Nancy. 2003. "From discipline to flexibilization? Rereading Foucault in the shadow of globalization." Constellations 10(2): 160-171. https:/ / doi.org/10.1111/1467-8675.00321.

Gamez, Patrick. 2018. “Did Foucault do Ethics? The ethical turn, Neoliberalism, and the problem of truth". Journal of French and Francophone Philosophy. 26(1): 107-133. https://doi.org/10.5195/ jffp.2018.818.

Jessop, Bob. 2016. The State: Past, present, future. Cambridge: Polity Press.

Hansen, Magnus. 2014. "Non-normative critique: Foucault and pragmatic sociology as tactical re-politicization." European Journal of Social Theory 19(1): 127-145. https:/ / doi.org/10.1177/1368431014562705.

Karlsen, Mads and Kaspar Villadsen. 2014. "Foucault, Maoism, Genealogy: the influence of political militancy in Michel Foucault's Thought." New Political Science 37(1): 91-117. https:/ / doi.org/10.1080/07393148. 2014.945251.

Kelly, Mark. 2014. Foucault and politics: A critical introduction. Edinburgh: Edinburgh University Press.

Kipnis, Andrew. 2008. "Audit cultures: neoliberal governmentality, socialist legacy, or technologies of governing?" American Ethnologist 35(2): 275-289.

Lorenzini, Danielle. 2016. "From conter-conduct to critical attitude: Michel Foucault and the art of not being governed quite so much." Foucault Studies 21: 7-21.

Senellart, Michel. 2007. "Course Context." In: Foucault M Security, Territory, Population. Lectures on Collège de France. New York: Palgrave Macmillan, pp. 477-507.

Trianfillou, Peter. 2012. New forms of governing: a Foucauldian inspired analysis. New York: Palgrave Macmillan.

Veyne, Paul. 2008. Foucault: as pensée, as personne. Paris: Albin Michel.

Zamora, Daniel, ed. 2014. Critiquer Foucault: les années 1980 et la tentation neoliberal. Belgium: Les Éditions Aden. 